\title{
DETERMINACIÓN DE OCRATOXINA-A POR HPLC CON DETECCIÓN POR FLUORESCENCIA (HPLC-FL): UN NUEVO MÉTODO ESTANDARIZADO PARA MUESTRAS DE TRIGO
}

\author{
OCHRATOXIN-A DETERMINATION BY HPLC WITH \\ FLUORESCENCE DETECTION (HPLC-FL): A NEW \\ STANDARDIZATION METHOD FOR WHEAT SAMPLES
}

\author{
Mario L. Teixeira (1), Daiane Pertuzzatti (2), Débora C. Leite (3), \\ Luis Flavio S. Oliveira (2), Alexandre M. Fuentefria (4)
}

(1) Curso de Medicina Veterinária - Instituto Federal Catarinense - Campus Concórdia, Brasil

(2) Centro de Ciências da Saúde - Universidade Comunitária Regional de Chapecó, Brasil

(3) PPGCA - Universidade Comunitária Regional de Chapecó - SC

(4) Departamento de Análises - Universidade Federal do Rio Grande do Sul, Brasil

\begin{abstract}
RESUMEN
El objetivo principal de este estudio fue evaluar la presencia de Ocratoxina-A(OTA) en los granos del trigo y harina del trigo realizadas por un nuevo método de determinación que usa la cromatografía líquida de alta resolución (CLAR) acoplada al descubridor del fluorimetrio. El experimento usó seis muestras de grano de trigo del lugar del almacenamiento diferente a la industria local de Chapeco (SC), Brasil Sur, en agosto, 2008. El extracto de OTA era llevado a cabo usando el acetonitrila:agua (120:80 v/v) como solventes. Después el suprenadante fue filtrado, y aplicado en la columna del inmunoafinidad específica a OTA. Además, la columna se lavó con agua y la toxina era el eluido con el metanol. La determinación del OTA se realizó por detección de fluorescencia acoplado al aparato de HPLC. Los volúmenes de OTA en los granos del trigo y harina del trigo eran entonces los determínate y los resultados mostraron una concentración de OTA menor que los límites exigidos por la legislación internacional. Palabras clave: Ocratoxina-A, CLAR, métodos del fluorescencia, trigo.
\end{abstract}

Este trabajo fue recibido el 4 de Mayo de 2009 y aceptado para ser publicado el 1 de Abril de 2010.

\section{INTRODUCTION}

Mycotoxins are secondary metabolites produced by some species of filamentous fungi. Under favorable conditions, as temperature and umit, the fungi are capable to produce poisonous effects in animals as in humans $(1,2)$.

The grains contamination by mycotoxins have been described in several vegetable phases crops, especially whether there are the presence of bioclimatic favorable conditions, insects infestation or other factors which increase the metabolic stress of the plants (2-4). The Food Agriculture Organization (FAO) indicated the aflatoxins, ochratoxin, T-2 toxin, deoxynivalenol, and fumonisins like the five main mycotoxins (5). On the other hand, in Brazil and in South America there are large prevalence of the patulin, trichothecenes and zearalenone than T-2 toxin (6).
The ochratoxins form a group of seven (7) secondary metabolites produced by some fungi belong to Aspergillus and Penicillium gender (8). However, the ochratoxin $\mathrm{A}$ (OTA) is the most natural abundant form in foods (7).

Chemically they are composed by non-enzymatic bond between a $ß$-fenilalanin and some isocumarine species by amide bond (5). It is happened under propitious conditions like water activity and temperatures above $30^{\circ} \mathrm{C}(9)$. The presence of OTA has been found in different components of the diet, such as corn, barley, bean, peanut, coffee, soy, wheat, saracen, rye, rice, sorghum, and Para chestnut (5).

The OTA effects on humans tissue has been reported like capable of causing nephrotoxic, nephrocarcinogenic and hepatotoxic events (5). However, the main toxic ef- 
fect is the nephrotoxicity. In line with this, the proximal tubule seems to be the structure that is most affected, where the OTA causes cytotoxicity and carninogenicity (10). The clinical manifestations communly are evidenciated by polyuria, and consequently renal tubular epithelium hyperphasia, and cells hepatic necrosis, which could be accompanied of enteritis (5).

Moreover, the FAO (11), for instance, recommends $5 \mu \mathrm{g} / \mathrm{kg}$ maximum limit for OTA in wheat, barley, and rye all at once its toxicology became know.

In front of this problem, several analytical methods for thin layer chromatography (TLC), gaseous chromatography (GC) and HPLC have been established for OTA analysis. Actually, all them attempt to reach to validation, which could offer exact, reproductive and rastreable results (12).

The foods contamination with toxigenic fungi or their mycotoxins are a grave problem in storage of fruits, cereals and others vegetables. Thus, the continuous analysis is imperative to maintain a good standard food quality. Otherwise, the mycotoxins contamination is capable to exert deleterious effects on human and animal health. Moreover, the mycotoxins can lead to loss economic business (13-16). Thereby this work proposed a new HPLC method to evaluate OTA in wheat grain and wheat flour samples leading to fast, cheap and robust analytical method to supplies a agribusiness demand, besides increase the possibilities of toxicological analysis in this area.

\section{MATERIALS AND METHODS Materials, reagents, equipments and operational conditions}

The standard solution was prepared using analytical reagent of OTA with $99 \%$ of purity (Sigma-Aldrich, St. Louis, MO, USA). The samples were evaluated using Liquid Chromatography Varian (Palo Alto, California, USA) with a C18 Microsorb-MV column (4,6 mm internal diameter X $250 \mathrm{~mm}$ length).

The operational conditions were performed using water/methanol/acetonitrile as mobile phase $(20 / 20 / 60 \%$ respectively) at $1,0 \mathrm{~mL} / \mathrm{min}$ flow rate and fluorescent detector. The elution was followed at $333 \mathrm{~nm}$ excitation and $460 \mathrm{~nm}$ emission wave-lenght. The retention time for OTA was from 4.8 to $5.2 \mathrm{~min}$.

\section{Analytical standardization of the method}

Linearity. The linearity was obtained from OTA reference solution $(10 \mathrm{ppb})$ which was used to originate a standardization curve at the follows concentrations $0.25,0.5,1.0,2.0$, and $4.0 \mathrm{ppb}$, in methanol HPLC grade (Vetec, Rio de Janeiro, Brazil). The linearity was evaluated by analysis of variance (ANOVA).
Reproducibility. Tests intra-day and inter-days were accomplished to determine the precision of the analytical method proposed. Different concentrations of OTA standard were prepared $(0.25,0.5,1.0,2.0$, and 4.0 $\mathrm{ppb}$ ) and analyzed in triplicates at three different days.

Limit of Detection (LOD) and Limit of Quantification (LOQ). The OTA LOD and LOQ were performed using standard solutions. From these solutions, the inclination coefficient from the calibration curve $(\alpha)$ and the standard deviation $(\sigma)$ from the straight line interception were calculated.

LOD and LOQ of OTA were using standard solutions. The data resulting in $3.3 \mathrm{\sigma} / \mathrm{a}$ and $10 \mathrm{\sigma} / \mathrm{a}$, respectively, where a is the coefficient of inclination from calibration curve and $\sigma$ is the standard deviation from intercept of the straight line (17).

Precision and accuracy. The precision and accuracy were obtained through of the recovery of the standard compound $(2.0 \mathrm{ppb})$ concentration added in reference solution. The test was accomplished in triplicates.

Robustness. Robustness of the proposed method was tested moving the $\mathrm{pH}$ from middle standard solution in $\pm 0,1$ units (for dissolution studies and stability).

\section{Analysis of OTA in wheat samples}

Sample. Six wheat grains samples from different places and wheat flour sample were obtained from a cooperative that store and industrialize these and other products in Chapeco city, Brazil. Such samples were collected on August 2008, in six storage location. The wheat samples were nominated in agreement with the origin storage location: storage location 1 , storage location 5, storage location 6 , storage location 7 , storage location 8 , and storage location 9 , and the wheat flour sample, was just named as wheat flour.

The wheat samples were collected with the grains in movement, in other words, during the shipment, discharge or grains transilagem, in regular time spaces of 15 minutes. It was collected 5 (five) samples of wheat from each storage location. Thereafter, they were reduced to single samples containing $1 \mathrm{~kg}$ every one. The same procedure was adapted for the wheat flour samples collection, before the packing procedures.

The lot samples were homogenized and reduced to bracket of $125 \mathrm{~g}$ for the quarteament technique at the laboratory. Thereafter, it was removed analytical subsamples in enough amounts for accomplishment of the analyses. These sub-samples were subjected to industrial grinding blender.

Extraction of OTA. The samples (50 $\mathrm{g}$ of wheat grains triturated and wheat flour) were homogenized in $200 \mathrm{~mL}$ of acetonitrile/water (120:80 v/v) solution during 
5 minutes. After that, they were filtered with filter paper and packed in flask properly identified.

Purification of the samples. From the extracted filtrate, only $1.5 \mathrm{~mL}(0.3125 \mathrm{~g}$ of sample in equivalence) was applied on OchratestTM immunoaffinity columns (Vicam, Watertown, MA, USA), with syringe and disposable needle. Subsequently, the column was washed with $5.0 \mathrm{~mL}$ of ultrapure water and the toxin eluated with $1.2 \mathrm{~mL}$ of methanol grade HPLC, through the column. The eluate was collected and maintained in refrigerator for subsequent HPLC analysis.

\section{RESULTS}

\section{Analytical standardization}

The chromatography conditions were adjusted starting from several injections of the standard solutions.

Figure 1 presents the chromatograms obtained from OTA standard solutions $(0.25,0.5,1.0,2.0$, and $4.0 \mathrm{ppb})$.

The retention time oscillated between 4.8 and 5.2 min., and the minimum and maximum retention times were the same for all the points. It was verified the variation of the area from chromatogram, which is related as the larger area as the concentration.

Linearity. Table 1 shows the linearity from OTA analysis's by proposed method.

Under the described experimental conditions, the graph of the calibration curve was built, and at table 1 the values obtained are illustrates from validation of this method.
The calibration curve was prepared plotting the values of the picks area from tested concentrations standard solutions ( 0.25 to $4.0 \mathrm{ppb}$ ). Area and concentration were submitted to the test of ANOVA to find the method linearity. The calibration equation and the correlation coefficient were calculated as $\mathrm{y}=102.69599 \mathrm{x}-0.37355$ $(r=0.9992)(Y=b . x+a$; where $y$ is arbitrary units of OTA picks, $b$ is the inclination of the straight line, $a$ is the intercept, and $\mathrm{x}$ is the concentration of the solution measured in $\mathrm{ppb}$ ). The correlation coefficient was of $0.9992(\mathrm{~F}=1.0396$, and $\mathrm{p}<0.01)$, indicating an excellent linearity to the proposed method (table 1 , and figure 2 ).

Reproducibility. The reproducibility of the new proposed method was expressed in the intra-day and inter-day tests. The values achieved for intra-day test were from $0.81 \%$ to $1.047 \%$, and for the inter-day rehearsals were from $1.33 \%$ to $1.67 \%$, what indicates a great reproducibility.

LOQ and LOD. The proposed method evaluates the LOQ and LOD, which showed $0.01 \mathrm{ppb}$ and 0.04 respectively. These results reinforce the use of this method for OTA analysis even at low concentration.

Precision and accuracy. To check the precision and accuracy of the new proposed method was considered the percentage of recovery of the standard added in the samples (scheme 1):

Recovery $\%=(\mathrm{Ct}-\mathrm{Cu}) / \mathrm{Ca} \times 100$

Scheme 1.

Where $\mathrm{Ct}$ is the total concentration of the analyte

\section{FIGURE 1}

OTA standard solutions chromatograms chromatograms of the standard solutions of OTA $(0.25,0.5,1.0,2.0$ and $4.0 \mathrm{ppb})$ in the wavelength of $330 \mathrm{~nm}$ excitation and $470 \mathrm{~nm}$ emission.

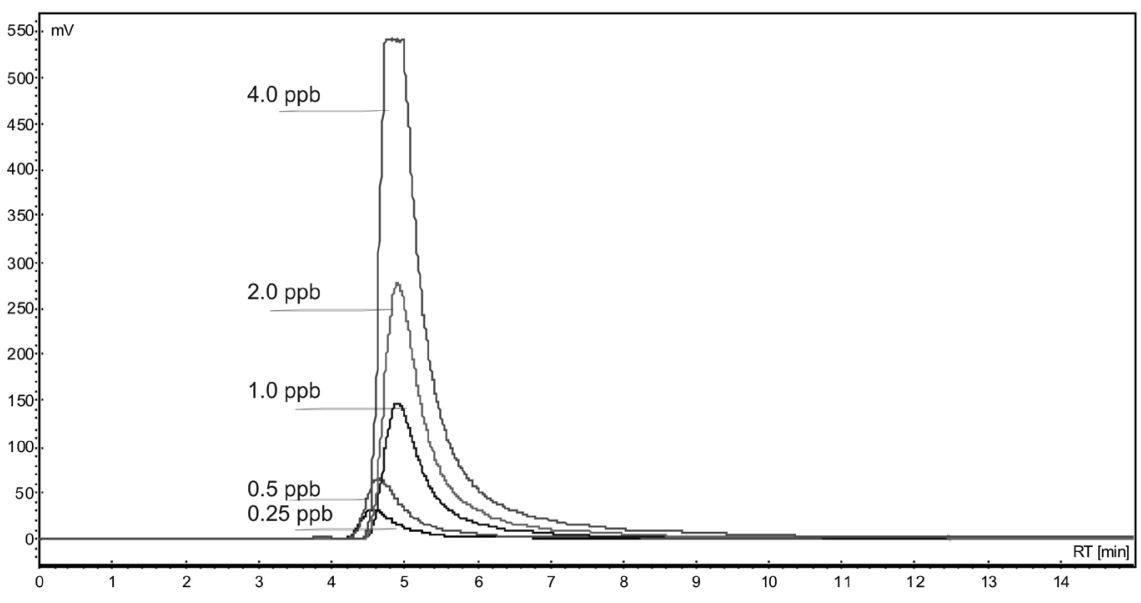


achieved; $\mathrm{Cu}$ is the concentration of the present analyte in reference solution; and $\mathrm{Ca}$ is the standard concentration of the analyte. The results are shown in the table 2. The recovery percentage of analyte was $101.44 \%$ to mobile phase proposed, indicating that this method have precision and accuracy, since the results shown to be reproducible.

Robustness. The $\mathrm{pH}$ variation in the standard dissolution ( $\pm 0,1$ unit) did not cause significant alteration on chromatogram areas. This fact leads us to suggest that the proposed method could be efficient to evaluate different samples with different $\mathrm{pH}$.

\section{Evaluation of the presence of OTA in grains} wheat stored and wheat flour

Chromatograms of the standardization of the method. The samples A1 and A2 used to the method standardization by the extraction technique, and to de-

\section{TABLE 1}

Analysis of variance (ANOVA) of the intensity of the peacks of each stardard solution of OTA in obtaining calibration curve through the proposed method.

\begin{tabular}{lccc}
\hline Variation Fonts & GL & SQ & QM \\
\hline Treatments & 1 & 18430 & 18430 \\
Blocks & 14 & 150560 & 10754.63 \\
F (treatments) & 17.8158 & \\
p (treatments) & 0.0000 & \\
F (blocks) & 1.0396 & $(\mathrm{p})$ \\
$\mathrm{p}$ (blocks) & 0.4717 & $<0.01$ \\
Tukey & $\mathrm{Q}$ & \\
Mean (1 and 2) & 5.5111 & \\
\hline The test of Turkey was used for confirmation of the data $(\mathrm{p}<0.01)$. &
\end{tabular}

\section{FIGURE 2}

Graph of the points of OTA calibration curve, according to the proposed method. The used points were: $0.25,0.5,1.0,2.0$ and $4.0 \mathrm{ppb}$. The curve was built in the program Galaxie Chromatography Workstation version 1.9.

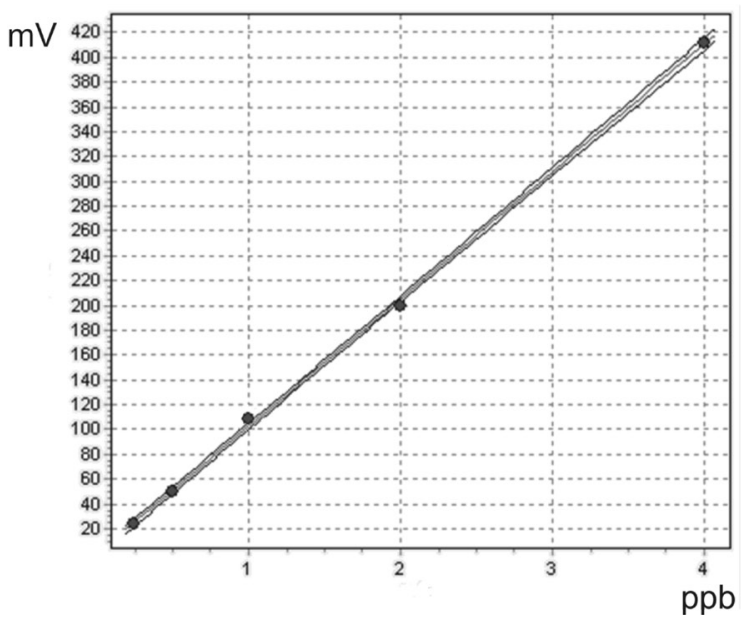

$$
y=b \cdot x+a
$$

Correlation coefficient $=0.9992$

$\mathrm{a}=-0.37355$

$b=102.69599$

$y=102.69599 . x-0.37355$ 


\section{TABLE 2}

Statistical analysis of the results obtained by the proposed method, in the assay with solution standard of OTA containing $2.0 \mathrm{ppb}$.

Statistic parameter Value found in the proposed method

$\begin{array}{cc}\text { Mean } \pm \text { SD } & 2.02 \pm 0.36 \\ \text { Recovery (\%) } & 101.44 \\ \text { Test-t significance } & 0.13 \\ \text { t-F de significance } & 1.21\end{array}$

\section{TABLE 3}

Correlation of the values of the area of the peack and concentration of OTA (in ppb) in the samples in study, according to the proposed method.

\begin{tabular}{|ccc|}
\hline Storage location & Area & OTA (ppb) \\
\hline 1 & 0.2 & 0.82 \\
5 & 0.3 & 0.88 \\
6 & 0.2 & 0.82 \\
7 & 0.3 & 0.88 \\
8 & 0.5 & 0.92 \\
9 & 0.6 & 0.97 \\
Wheat flour & 16,06 & 9.20 \\
\hline Source: data of the research. & & \\
\hline
\end{tabular}

\section{FIGURE 3}

Chromatograms of the samples A1 and A2, analyzed by HPLC-FL according to the method proposed for quantification of OTA. (A) Sample A1. (B) Sample A2.
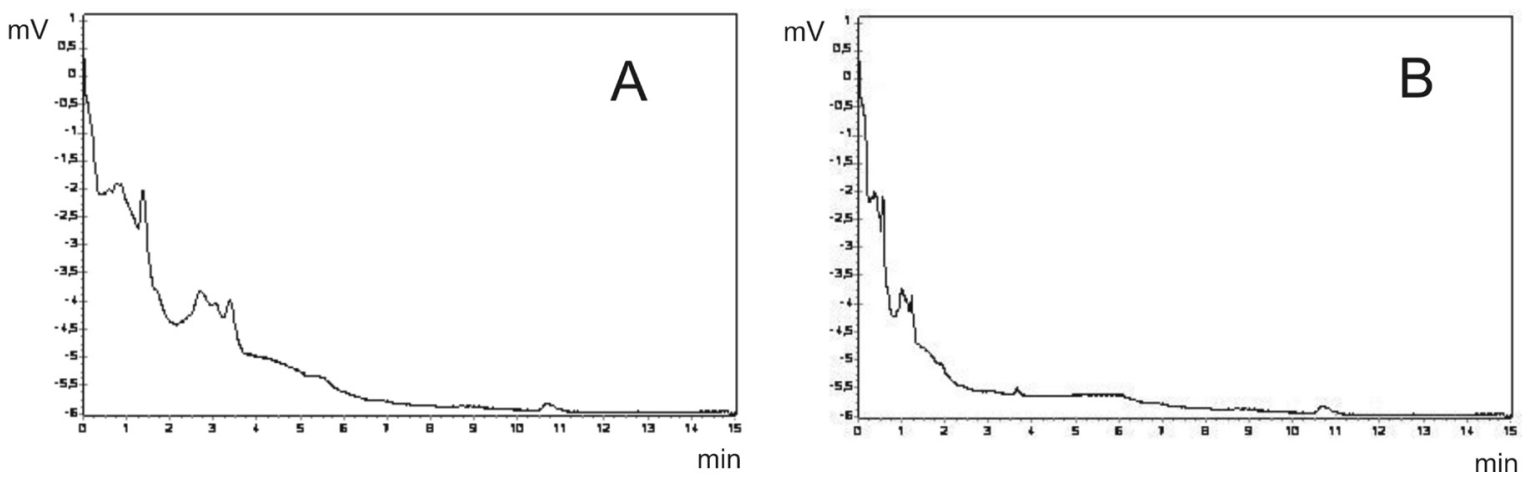
oxynivalenol purification, were analyzed by HPLC-FL in according to the proposed method. The presence of toxin in the samples analyzed was identify and quantify by chromatograms generated from OTA standard solutions, where the retention pick was not observed during approximately 5 minutes (figure 3).

On the other hand, the samples A3 and A4, which were added to the vial $1.0 \mathrm{ppb}$ and $4.0 \mathrm{ppb}$ of OTA (100 $\mu \mathrm{L}$ ) respectively, the presence of the toxin was observed with retention pick in approximately 5 minutes in the chromatograms (figure 4).

Quantification of OTA in the samples in study. In figure 5 , it can be observed that the toxin was not detected in all samples.

\section{FIGURE 4}

Chromatograms of the sample A3 with addition of $1.0 \mathrm{ppb}$ of OTA (A) and of the sample A4 with addition of 4.0 ppb of OTA (B), analyzed by HPLC-FL according to the proposed method.
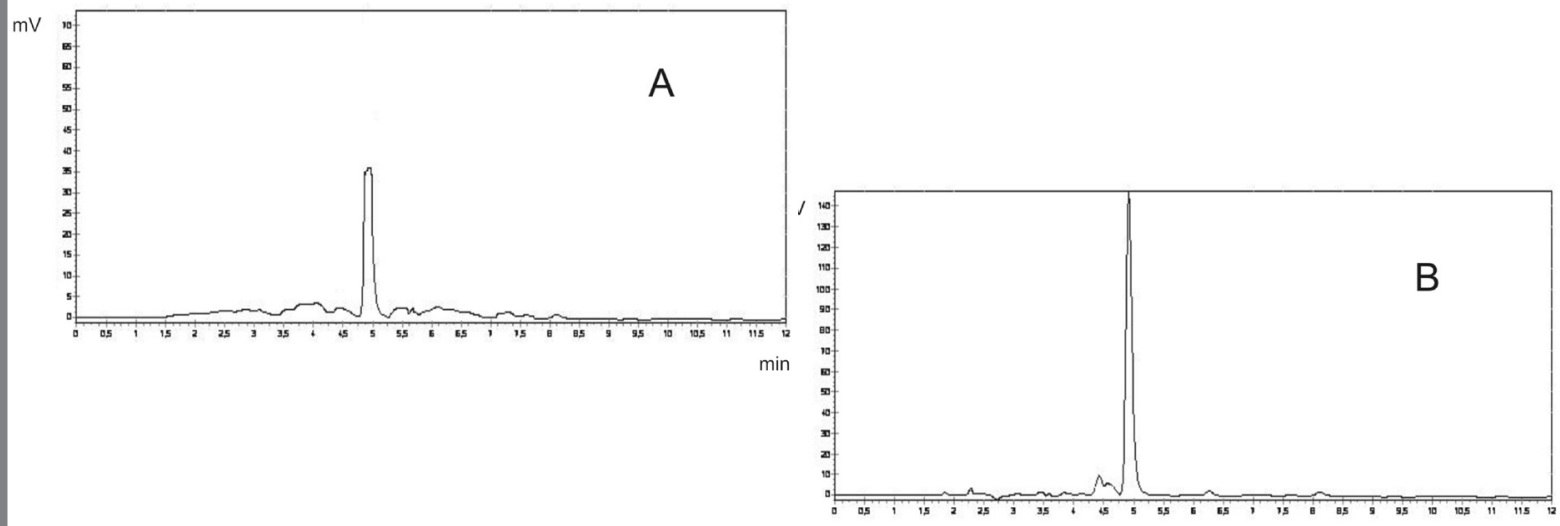

\section{FIGURE 5}

Chromatograms of the samples of the storage locations and of the wheat flour analyzed by HPLC-FL, according to the method proposed in the wavelength of $330 \mathrm{~nm}$ excitation and $470 \mathrm{~nm}$ emission.

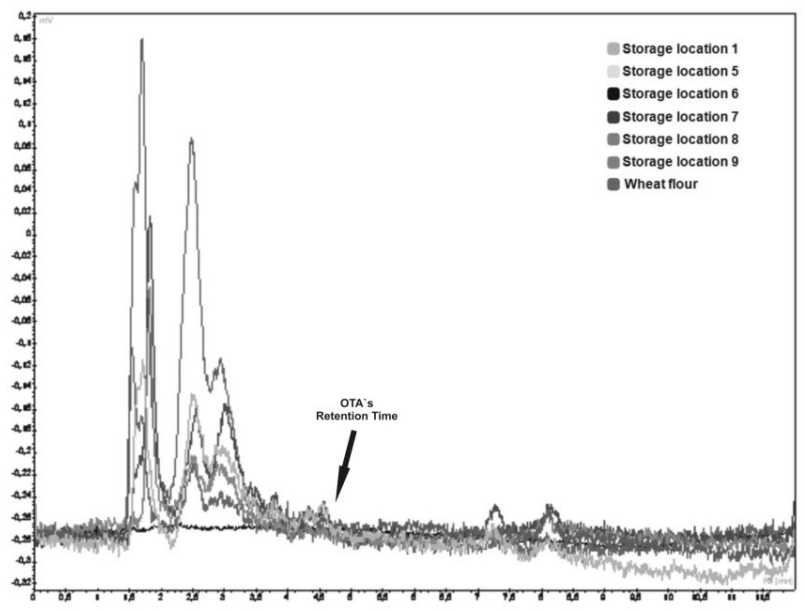




\section{DISCUSSION}

The reproducibility, the efficiency, and the linearity of the proposed analytical method showed to be appropriate to determine OTA levels in wheat samples, once the standardization allowed an analysis of the presence and amount of OTA in a reduced time, emphasizing itself a new experimental condition of analysis, which could be used in the routine laboratorial as an alternative OTA analysis through of HPLC-FL method.

Regarding the OTA analysis in food samples, resembling results were achieved by Caldas; Silva; Oliveira (18), in Brasilia city, on July 1998 to December 2001 period, whereas 366 analyzed samples contained levels detected of OTA $(<25 \mu \mathrm{g} / \mathrm{kg})$.

However, there are many studies which found OTA in wheat and flowed. For instance, the work accomplished by Furlong (19) in available wheat products from Rio Grande and Pelotas supermarkets cities during 1996 to 1997 shown presence of OTA at concentration among $18 \mu \mathrm{g} / \mathrm{kg}$ to $26 \mu \mathrm{g} / \mathrm{kg}$.

Malmann (20) investigated the presence of OTA in 924 samples of winter cereals on March 1998 to March 2003 period. In those analysis there were found 22 samples polluted with OTA, with $40.2 \mathrm{ppb}$ from wheat sample as maximum level achieved. In line with this, Vieira (21) evaluated the quality of wheat flours from South area of Rio Grande do Sul State, Brazil, on 1995 to 1996 period. The analysis had shown the occurrence of some mycotoxins, OTA and zearalenone, with $12 \mu \mathrm{g} /$ $\mathrm{kg}$ and $53 \mu \mathrm{g} / \mathrm{kg}$, respectively.

Stamford (22) analyzed the aflatoxins and OTA occurrences in carcasses, eatable and processed viscera of birds from different areas from Brazil. To the total samples analyzed, $12 \%$ were positive, which $10.8 \%$ were represented by aflatoxins, and $1.2 \%$ by OTA. The presence of OTA was prevalent in products originated from South and Southeast of Brazil, while the aflatoxins prevailed in samples from different areas from Pernambuco State.

Juan (23) analyzed the OTA incidence in 61 samples of wheat bread and corn bread from Portugal. The OTA incidence was $12.9 \%$ and $70 \%$ to the wheat and corn bread, respectively.

Santurio and Malmann (24) in order to evaluate the OTA presence in died swine frozen analyzed 73 swine serum samples from Concordia-SC and Bom Retiro do Sul-RS areas during the months of October and November, 1991. In 9 samples (13.2\%) there were found lines of OTA $(<1 \mathrm{ng} / \mathrm{mL})$. This achieve emphasizes the need to research the OTA presence in animal rations.

Despite of this, there is not much information about OTA contamination in wheat grains produced in Brazil, or even in wheat derived products. This fact did not allow carry out others comparisons with the results obtained by this work.

Furlong (19) analyzed wheat grains harvested among 1988 to 1990, and stored in South of Brazil granary (12 samples from Brazil, 4 samples from Argentina and 2 samples from Uruguay). In those analysis, the author found just one sample from 1988 crop the presence of OTA at $0.04 \mu \mathrm{g} / \mathrm{g}$, and three samples from 1990 crop contained deoxynivalenol (DON) at $0.40 \mu \mathrm{g} / \mathrm{g}$. In other words, these results in despite of the present work demonstrate that the detection of OTA in wheat samples is possible, even at low concentration. However, the present work demonstrated more sensibility than Furlong method.

\section{CONCLUSIONS}

The results of this work indicated that the proposed method is efficient for detection and quantification of OTA in wheat grains and wheat flour, since their indicators presented was able to recovery $101.44 \%$ for OTA; offered good precision, with a coefficient of variation of 0.9992 , and a detection limit in the samples of $0.01 \mathrm{ppb}$.

The present work still showed that all of samples $(100 \%)$ collected contained insignificant amounts of OTA. The levels of OTA in analyzed samples were minor than to maximum limits established by the importers that trade with the cooperative which consented the collects, as well as for the international legislations.

The main objective of this study was to evaluate the presence of Ochratoxin A (OTA) in wheat grains and wheat flour samples using a new high performance liquid chromatography (HPLC) method. The experiment used six wheat grain samples from different industry storage place from Chapeco (SC), South Brazil, on August 2008. The OTA extraction was carried out using acetonitrile:water $(120: 80 \mathrm{v} / \mathrm{v})$ as solvent. Thereafter, the supernatant was filtered, and applied on OTA-specific immunoafinity column to HPLC. Furthermore, the column was washedAwith water and the toxin was eluted with methanol. The OTA wheat grains and wheat flour concentration were analyzed by a fluorescence detector coupled to the HPLC apparatus. The results showed a smaller OTA concentration than the limits set by international legislation.

Key words: Ochratoxin A, HPLC, fluorometric methods, wheat.

Correspondence to the author:

Dr.

Alexandre Meneghello Fuentefria 
Departamento de Análises

Universidade Federal do Rio Grande do Sul,

UFRGS

Avenida Ipiranga, 2752.

Sala 304C.

Santa Cecília 90610-000

Porto Aleore_RS - Brasil

E-mail:alexmf77@gmail.com

\section{BIBLIOGRAPHY}

1. Peraica M, Radic B, Lulic A, Pavlovic M. Efectos tóxicos de lãs micotoxinas em el ser humano, Bol Org Mund Salud 2000; 77: 754-766.

2. Sabino M. Micotoxinas em alimentos. In: Oga, S.; Camargo, M. M. de A.; Batistuzzo, J. A. de O. Fundamentos de toxicologia, 3a. edição. São Paulo: Atheneu, 2008.

3. Gonçalez E, Felicio JD, Pinto MM. Análise de micotoxinas no instituto biológico de 1989 a 1999 , Biolog 2001; 3: 15-19.

4. Bennett GA, Richard JL. Influence of processing ou Fusarium mycotoxins in contaminated grains, Food Tech 1996; 50: 235-238.

5. Scussel VM. Micotoxinas em alimentos. Florianópolis: Insular, 1998.

6. Fink-Gremmels J. Mycotoxins in cattle feeds and carry-over to dairy milk: A review, Food Addit Cont 2008; 25: 172 - 180.

7. Midio AF, Martins DI. Toxicologia de alimentos. São Paulo, Varela, 2000.

8. Lindner E. Toxicologia de los alimentos. 2 ed. Zaragoza, Acribida, 1995.

9. Jay JM. Microbiologia de alimentos. 6 ed. Porto Alegre, Artmed, 2005.

10. Benford D, Boyle C, Dekant W, Fuchs R, Gaylor DW, Hard G. Ochratoxin A. International Programme on Chemical Safety (INCHEM), Joint FAO/WHO Expert Committee on Food Additives (JECFA). Monographs \& Evaluations. WHO Food Addit, série 41, 2001.

11. IARC. International Agency for Research on Cancer. Monographs on the evaluation of carcinogenic risks to humans. Some naturally occurring substances: food items and constituents, heterocyclic aromatic amines and mycotoxins. Lyon, 1993; 56: 599.

12. Josephs RD, Derbyshire M, Stroka J, Emons H, Anklam E. Trichothecenes: reference materials and method validation, Toxicol Let 2004; 153: 123-132.

13. Oliveira MS, Prado G, Abrantes FM. Incidência de aflatoxinas, desoxinivalenol e zearalenona em produtos comercializados em cidades do Estado de Minas Gerais no período de 1998 - 2000, Rev Inst Adolf Lutz 2006; 61: 1-6.

14. Lazo RF, Sierra G. Investigación del efecto de las micotoxinas en el ser humano, Rev Ibero Micol 2008; 25: 7-11.

15. Krska R, Schubert-Ullrich P, Molinelli A, Sulyok M, MacDonald S, Crews C. Mycotoxin analysis: an update, Food Addit Cont 2008; 25: 152-163.

16. Whitaker TB. Sampling foods for mycotoxins. Food Addit Cont 2006;. 23: 50-61.

17. European Agency for the Evaluation of Medicinal Products. ICH Topic Q2B Note for Guideline on Validation of Analytical Procedures: Methodology GPMP/ICH/281/95. FAO - Organización de las naciones unidas para la agricultura y la alimentación. Reglamentos a nivel mundial para lãs micotoxinas em los alimentos y en las raciones en el año 2008.

18. Caldas ED, Silva SC, Oliveira, JN. Aflatoxinas e ocratoxina A em alimentos e riscos para a saúde humana, Rev Saúde Públ 2005; 36(3): 319-323.

19. Furlong EB, Soares LMV. Mycotoxins and fungi wheat harvested during 1990 in test plots in the state of São Paulo, Brazil. Mycopath 1995; 131(3): 185-190.

20. Mallmann CA. Determination of fungal microbiota and mycotoxins in brewers grain used in diary cattle feeding in the state of Bahia. Braz Food Control 2006; 18: 404-408.

21. Vieira A P. Ocorrência de micotoxinas e características físico-química de farinhas comercializadas na zona sul do Rio Grande do Sul, Rev Soc Bras Cienc Tecnol Alim 1999; 19: 221-225.

22. Stamford TLM, Vilar EA, Bastos STG, Silva CGM. Pesquisa micotoxicológica de produtos avícolas in natura e processados, Bol Cent Pesq Proces Alim 2005; 23: 135-160.

23. Juan C, Pena A, Lino C, Moltó JC, Manes J. Levels of ochratoxin $\mathrm{A}$ in wheat and maize bread from the central zone of Portugal, Intern J Food Microb 2008; 127: 284-289.

24. Santurio JM, Malmann CA. Ocratoxina A em Soro de Suínos na Região Sul do Brasil. Horm Veter 1993; 13: 32-34. 